\title{
Gastrointestinal tract schwannomas and brief review of literature
}

\author{
Şükrü Çolak' (D), Bünyamin Gürbulak' (D), Gürhan Çelik (D), Hasan Bektaş ${ }^{1}$ (D), Nevra Dursun²(D) \\ ${ }^{1}$ Clinic of General Surgery, University of Health Sciences Istanbul Training and Research Hospital, Istanbul, Turkey \\ ${ }^{2}$ Department of Pathology, University of Health Sciences Istanbul Training and Research Hospital, Istanbul, Turkey
}

\begin{abstract}
Schwannomas originating from Schwann cells arise from the peripheral nerve sheath and are slow-growing, benign tumors that originate mostly from the mesenchyme. It appears equally in both sexes. Schwannomas are often seen in the $3^{\text {rd }}$ and $5^{\text {th }}$ decades of life. Schwannomas can be seen everywhere where peripheral nerves are seen. Gastrointestinal schwannomas constitute 2-6\% of all submucosal masses, and the stomach is the most common region (60-70\%). Endoscopic Ultrasound (EUS)-guided sampling of gastrointestinal submucosal lesions has made it possible to achieve preoperative differential diagnosis. Patients diagnosed with gastrointestinal schwannomas between January 2005 and December 2017 were included in this study. Three out of six patients were females. Median age was 52.5 (44-76) years. Schwannomas were found in two patients in the gastric region, one patient in the appendiceal region, two patients in the colon and one patient in the perianal region. Primary schwannomas are usually benign. Radical resection with free margin is necessary because of the risk of malignant degeneration; chemo and radiotherapy response is indeterminate, and local recurrence rates are high.
\end{abstract}

Keywords: Gastrointestinal schwannomas, gastrointestinal submucosal mass, immunohistochemistry

Cite this article as: Çolak Ş, Gürbulak B, Çelik G, Bektaş $H$ Dursun N. Gastrointestinal tract schwannomas and brief review of literature. Turk J Surg 2021; 37 (4): 408-412

Corresponding Author Bünyamin Gürbulak

E-mail: bgurbulak@gmail.com

Received: 08.08.2018

Accepted: 10.11.2021

Available Online Date: 31.12 .2021

( C) Copyright 2021 by Turkish Surgical Society Available online at www.turkjsurg.com

DOI: $10.47717 /$ turkjsurg.2021.4286

\section{INTRODUCTION}

Schwannomas originating from Schwann cells arise from the peripheral nerve sheath and are slow-growing, benign tumors that originate mostly from the mesenchyme.

These tumors could be found wherever peripheral nerves are seen, in the head and neck, spinal cord and extremities according to the order of frequency $(1,2)$.

These tumors are very rare in the gastrointestinal system and in visceral localizations such as mediastinum, retroperitoneum, pelvis, and etc. (3).

Gastrointestinal schwannomas constitute 2-6\% of all submucosal masses and the stomach is the most common site (60-70\%) (4).

It appears equally in both sexes. Schwannomas are often seen in the $3^{\text {rd }}$ and $5^{\text {th }}$ decades of life (5).

Immunohistochemical examination is necessary for definite diagnosis, and it is difficult to make preoperative diagnosis endoscopically because they are usually covered with smooth mucosa (6).

However, in recent years, endoscopic ultrasound (EUS)-guided sampling of submucosal lesions has made it possible to achieve preoperative differential diagnosis of gastric submucosal tumors (7).

In this study, we aimed to discuss the patients with gastrointestinal schwannomas in light of the current literature.

\section{MATERIAL and METHODS}

In this study, patients who underwent operation due to the gastrointestinal mass and were reported as schwannoma in the pathological examination in Istanbul Training and Research Hospital between January 2005 and December 2017 were retrospectively analyzed. 
No diagnosis was obtained in any of the patients in the preoperative period. Preoperative findings were compared with postoperative ones. Surgery, follow-up and recurrence rates of the patients were reviewed in light of the literature.

Local ethics committee approval was obtained from Istanbul Training and Research Hospital for this study. All data were collected from the accessible computer database system of the hospital. Written informed consent was obtained from all patients included in this study. The authors declare that the research was conducted according to the principles of the World Medical Association Declaration of Helsinki "Ethical Principles for Medical Research Involving Human Subjects".

\section{Statistical Analysis}

Statistical analyses were carried out using the Statistical Package for Social Sciences version 15.0 (SPSS for Windows 15.0, Inc, Chicago, IL, USA).

The data were evaluated by descriptive statistical methods (Mean and standard deviation, median).

\section{RESULTS}

Three out of six patients were females. Mean age was 52.5 (4476) years. Schwannoma was found in two patients in the gastric region, one patient in the appendiceal region, two patients in the colon and one patient in the perianal region. Table 1 shows patient demographics and tumor localizations of tumors.

Four out of six patients underwent surgery and two underwent endoscopic polypectomy.

One of the patients with gastric schwannoma was 43 years old and female. Computerized tomography (CT) of the abdomen demonstrated a bulbous mass that infiltrated the stomach corpus, pancreatic corpus and tail and splenic flexure of the colon. Fluid collection was also detected in both pleural spaces and in the pelvic region. Patient's colonoscopy was normal. On endoscopic examination of the upper gastrointestinal tract, ulcer lesions were detected in the posterior wall of the fundus and corpus junction about $2 \mathrm{~cm}$ in size. Biopsies from the ulcer site were compatible with gastric ulcer and necrosis and was not diagnostic. In the operation, pancreas and colon-infiltrated mass and ascites were detected in the abdomen originating from the stomach large curvature. The mass was removed from the tissues by applying wedge resection to the stomach wall; and ascite sampling was performed. Pathology of the patient was $6.5 \times 5.5 \times 5.5 \mathrm{~cm}$ in size, $2 \mathrm{~cm}$ in width on the mucosa and $1.6 \mathrm{~cm}$ in depth in the ulcerated area. IHC staining revealed S-100 (+), CD-117 (-), CD-34 (-), SMA (-), and Myosin (-). Ascite material was negative for tumor.

Another patient who was referred to our hospital with dyspeptic complaints was a 43-year-old female. The patient underwent gastroscopy, and a submucosal mass was detected in the middle of the stomach major curvature. Biopsy results of the patient were not diagnostic. The patient underwent surgery with gastrointestinal stromal tumor diagnosis because a submucosal mass was detected in the anterior wall of the stomach corpus about $8 \mathrm{~cm}$ in abdominal $\mathrm{CT}$ scanning. The mass was resected by wedge resection and sent to frozen, and the resection was expanded, and the procedure was terminated as the surgical margin would be negative. The lesion was an external nodular tumor, $9 \times 7 \times 6.5 \mathrm{~cm}$ in size, and IHC staining was as follows; $S-100$ (+), CD-117 (-), CD-34 (-), Desmin (-), SMA (-) and B catenin (-).

Another patient was a 65-year-old male with schwannoma of the appendix. In the operation, perforated appendicitis and abdominal abscess were detected, and appendectomy was performed. Pathological examination of the specimen revealed 0.7 $\mathrm{cm}$ in size with phlegmonous appendicitis, local peritonitis and intramuscular placement at the distal end. $\mathrm{IHC}$ staining was as follows; S-100 (+), CD-117 (-), CD-34 (-), SMA (-).

A 44-year-old male patient who had been operated for a perianal fistula had an anterior mass in the distal anal canal localized distant from the fistula region. With fistula surgery, the mass was totally excised. A thick solid mass in $0.6 \mathrm{~cm}$ size was found in the border of a $3.5 \times 3 \times 2.5 \mathrm{~cm}$ medial hemorrhagic cystic lesion. The findings of $\mathrm{HC}$ staining were as follows; S-100 (+) and SMA (-).

Another patient was a 58-year-old female with colonic schwannoma. Four sessile colon polyps $0.5 \mathrm{~cm}$ in diameter were detected in the sigmoid colon on colonoscopy; and polypectomy was performed. Pathologic results showed schwann cell-predominant, infiltrating $0.4 \mathrm{~cm}$ nodular formation; and IHC examination revealed S-100 (+), CD-117 (-), CD-34 (-), SMA (-) and Desmin (-).

Table 1. Patient's demographics and tumor localization

\begin{tabular}{|l|c|c|c|}
\hline \multirow{2}{*}{ Localization } & Patient $(\mathbf{n})$ & Age & Gender \\
\hline \multirow{2}{*}{ Large bowel } & 1 & 43 & $\mathrm{~F}$ \\
\cline { 2 - 4 } & 1 & 44 & $\mathrm{~F}$ \\
\hline Appendix & 1 & 58 & $\mathrm{~F}$ \\
\hline Perianal region & 1 & 72 & $\mathrm{M}$ \\
\hline F: Female, M: Male. & 1 & 65 & $\mathrm{M}$ \\
\hline
\end{tabular}


Another was a 72-year-old male patient with diminutive polyp on the sigmoid colon in the screening colonoscope. Pathologic examination revealed benign mesenchymal tumors of $0.3 \times 0.2 \times 0.1 \mathrm{~cm}$ in size composed of stem cells at mucosa; and submucosa and S-100 (+), CD-117 (-), CD-34 (-), SMA and Desmin (-) in IHC examination.

Mean tumor size was 7.25 (6.5-9) cm for the stomach, $0.7 \mathrm{~cm}$ for the appendix, $0.6 \mathrm{~cm}$ for the distal anal canal, and 0.3 and $0.4 \mathrm{~cm}$ for the lesions on the colonic segments.

\section{Follow-up of the patients}

Patients were followed up with an annual total body CT scan and upper and lower gastrointestinal endoscopy. Mean follow-up period of the patients was 7.8 (5-12) years, and no recurrence or metastatic lesion was detected.

\section{DISCUSSION}

Schwannomas originate from ectoderm and neural sheath. Gastrointestinal tract schwannomas frequently originate from the autonomous nervous system, including Auerbach's plexus and less commonly Meissner's plexus $(8,9)$. Auerbach's plexus originates and grows on the wall and is not pedunculated. Those originating from Meissner's plexus extend the lumen like pedunculated polyps (10). Despite the presence of radiation and hereditary neurofibromatosis in the etiology of peripheral nerve tumors, no such association has been demonstrated in gastrointestinal schwannomas.

Although most mesenchymal tumors of the gastrointestinal tract are GIST, schwannomas constitute $1.4 \%$ to $6.3 \%$ of mesenchymal tumors and are symptomatic according to the region $(7,11)$.

In order of frequency, stomach (83\%), small intestine (12\%), colon and rectum (2-6\%) are the most common schwannoma localizations in the gastrointestinal tract.Gastric schwannomas constitute approximately $0.2 \%$ of all gastric tumors and $4 \%$ of benign gastric neoplasms $(12,13)$.

Colon and rectum-involved schwannomas not associated with von-Renklinghausen disease have been reported to be quite rare $(2-6 \%)$ in the literature (9). Schwannomas are in the retroperitoneal region at a rate of $0.5-5 \%$ (14).

The symptoms of lesions change according to their size and location. If located in the stomach, gastric discomfort, hemorrhage or rarely gastric outlet obstruction by luminal or extraluminal effect may cause ileus and associated pain, fever, fatigue.

When localized in the small intestine, the same symptoms may appear with abdominal pain, intussusception, degeneration, ileus; and when localized in the colon and rectum, there may be rectal bleeding or colonic obstruction (15).

Due to submucosal localization, endoscopic biopsies usually result negative (16). In submucosal localization, it causes mucosal erosions and can cause invasion, adhesions and intestinal obstruction of the surrounding tissues by bleeding and exophytic growth (17).

In our series, hemorrhage and anemia were present in a patient with schwannoma of the stomach, and at the same time, it invaded the pancreas and the left colon. The lesion of the first patient caused mucosal compression ulcer and consequently, anemia. As a result, both patients were not diagnosed preoperatively and intraoperatively of the second patient, and schwannoma diagnoses were obtained after immunohistochemical staining.

Lesions showing exophytic growth press on other organs or veins. Those close to the pylorus may block the passage. Schwannomas in the GIS have a peripheral cuff of lymphoid cells (18).

Since schwannomas have a slow growth pattern, vascularity accompanies this and necrosis does not occur. In GIST, rapid growth does not accompany vascularity and intratumoral necrosis can be seen $(19,20)$. Schwannomas with adrenal localization may show septa and cystic changes not seen in other retroperitoneal tumors (21)

Due to the fact that schwannomas have a peripheral lymphoid cuff, this lymphoid tissue shows high FDG uptake in PET. FDG uptake (SUVmax) varies to 3.3 and 7.1 according to metastatic tumor and malignant tumor (22).

Schwannomas are distinguished from other benign lesions by immunohistochemical and microscopic findings. In these tumors, while S-100 protein is strongly positive, c-KIT (CD-117), CD-34, SMA and Desmin are negative. Although S-100 protein is $30-40 \%$ positive in neurofibroma, it is 100\% positive in schwannoma. In gastrointestinal stromal tumors, C-KIT CD-117 and CD34 are $70 \%$ positive while S-100 protein is negative. Lymphoid cuff, lymphoid infiltration, cellular heterogeneity, nuclear atypia and microtrabecular pattern are seen in schwannoma and absent in GIST (23).

Glial Fibrillary Acidic Protein (GFAP) is used to separate schwannomas from Gastrointestinal Autonomic Nerve Tumors (GANTs). Schwannoma showed GFAP with 63.6\%, and GANTs could not be shown. In differential diagnosis, S-100 positive-stained gastrointestinal clear cell sarcoma and metastatic melanoma should also be separated. Somatic NF-2 mutations in soft tissue schwannomas are rare in gastric schwannomas (24).

Gastric schwannomas are usually seen in the $3^{\text {rd }}$ and $5^{\text {th }}$ decades of life. It is often solitary tumors originating from the nerve cells in the fundus and corpus of stomach. Homogeneous appearances of schwannoma in CT scan can help to distinguish them from GISTs. Hong et al. (25) reported a series of 16 cases with a homogeneous pattern in 13 cases and 3 cases with cystic changes in 2008. 
Imaging methods such as tomography, MR and endoscopy are limited in accurate diagnosis. EUS-guided biopsy can help the diagnosis. Takasumi et al. (26) have diagnosed 4 out of 6 cases (66.7\%) with EUS-guided biopsy in the preoperative period.

The incidence of colon schwannoma is not fully known. In the series of Voltaggio et al. (27) consisting of 20 cases, the most common localization in the GIS is the stomach followed by the colon.

Schwannomas in GIS are relatively rare compared to GIST that have mesenchymal origins. This ratio is 50-100/1. In smaller scale studies, there are rates reported as 1 schwannoma vs. 8-14 GIST $(12,28,29)$.

Inagawa et al. (30) have examined the colon-rectum localized schwannomas in the Japanese literature and found that the most frequent site is the rectum with $45.7 \%$. In this study, right colon placement, with the exception of appendiceal placement, has been found to be $19.6 \%$.

Our results showed that 4 out of 6 patients (67\%) had large intestine and 2 out of 6 patients (33\%) had gastric schwannomas. sigmoid colon and stomach are more common localizations in our series.

Tumor size and mitotic index significance have not been reported in the literature for gastric schwannomas. In this regard, Voltaggio et al. (27) have reported that some gastric schwannomas show more than $10 \mathrm{~cm}$ and minor mitotic rates 5/50 (HPFs), none of which exhibit aggressive behavior. Long-term follow-up results of 10/50 (HPFs) schwannoma with high mitotic index are not known. Therefore, patients with Ki-67 proliferative index and high (>5) mitotic index should be followed closely in terms of recurrence and metastases. Primary schwannomas are usually benign. Radical resection with clean borders is necessary because of the risk of malign degeneration, chemo and radiotherapy response is indeterminate, and local recurrence rates are high (30\%).

Nowadays, pre-operative submucosal lesions are diagnosed with EUS-guided sampling and IHC staining.

The most important drawback of this study is the retrospective nature, single-center formation and EUS-guided sampling being not used.

\section{CONCLUSION}

To conclude, schwannomas are benign tumors arising from the peripheral nerve sheath. Preoperative diagnosis of these tumors is important. If the diagnosis is made preoperatively, surgical margin will be negative for treatment. Radical lymph node dissection is not necessary since it has a benign nature and does not cause lymph node metastasis. Recurrence and malignant transformation may occur if free surgical margin has not been not achieved. Since chemotherapy and radiotherapy are not effective for these tumors, it is very important to remove the tumor with negative surgical margins.

Ethics Committee Approval: The ethical approval for this study was obtained from SBÜ İstanbul Training and Research Hospital Clinical Research Ethics Committee (Decision No: 2512, Date: 08.08.2020).

Informed Consent: Informed consent was obtained from the son of the patients.

Peer-review: Externally peer-reviewed.

Author Contributions: Concept - S..Ç., B.G.; Design - H.B., B.G.; Supervision - H.B.; Materials - Ş.Ç., G.Ç. ND, ; Data Collection and/or Processing - G.Ç., Ş.Ç, N.D.; Analysis and/or Interpretation - H.B., B.G.; Literature Search - B.G.; Critical Reviews - H.B.

Conflict of Interest: No conflict of interest was declared by the authors. Financial Disclosure: The authors declared that this study has received no financial support.

\section{REFERENCES}

1. Lauwers GY, Erlandson RA, Casper ES, Brennan MF, Woodruff JM. Gastrointestinal autonomic nerve tumors. A clinicopathological, immunohistochemical, and ultrastructural study of 12 cases. Am J Surg Pathol 1993; 17: 887-97. [CrossRef]

2. Das Gupta TK, Brasfield RD, Strong EW, Hajdu SI. Benign solitary Schwannomas (neurilemomas). Cancer 1969; 24: 355-66. [CrossRef]

3. Almo KM, Traverso LW. Pancreatic schwannoma: an uncommon but important entity. J Gastrointest Surg 2001; 5: 359-63. [CrossRef]

4. Catania G, Puleo C, Cardi F, Catalano F, luppa A, Buffone A. Malignant schwannoma of the rectum: a clinical and pathological contribution. Chir Ital 2001; 53: 873-7.

5. Moriya T, Kimura W, Hirai I, Takeshita A, Tezuka K, Watanabe T, et al. Pancreatic schwannoma: Case report and an updated 30-year revi-ew of the literature yielding 47 cases. World J Gastroenterol 2012; 18: 1538-44. [CrossRef]

6. Hirota S, Isozaki K, Nishida T, Kitamura Y. Effects of loss-of-function and gain-of-function mutations of c-kit on the gastrointestinal tract. J Gastroenterol 2000; 35 Suppl 12: 75-9.

7. Mekky MA, Yamao K, Sawaki A, Mizuno N, Hara K, Nafeh MA, et al. Diagnostic utility of EUS-guided FNA in patients with gastric submucosal tumors. Gastrointest Endosc 2010; 71: 913-9. [CrossRef]

8. Fotiadis Cl, Kouerinis IA, Papandreou I, Zografos GC, Agapitos G. Sigmoid schwannoma: a rare case. World J Gastroenterol 2005; 11:507981. [CrossRef]

9. Nonose R, Lahan AY, Santos Valenciano J, Martinez CA. Schwannoma of the colon. Case Rep Gastroenterol 2009; 3: 293-9. [CrossRef]

10. Tsunoda C, Kato H, Sakamoto T, Yamada R, Mitsumaru A, Yokomizo H, et al. A Case of benign schwannoma of the transverse colon with granulation tissue. Case Rep Gastroenterol 2009; 3: 116-20. [CrossRef]

11. Atmatzidis $S$, Chatzimavroudis $G$, Dragoumis D, Tsiaousis P, Patsas A, Atmatzidis K. Gastric schwannoma: a case report and literature review. Hippokratia 2012; 16: 280-2.

12. Klimo P Jr, Rao G, Schmidt RH, Schmidt MH. Nerve sheath tumors involving the sacrum. Case report and classification scheme. Neurosurg Focus 2003; 15: E12. [CrossRef] 
13. Chetty R. Reticular and microcystic schwannoma: a distinctive tumor of the gastrointestinal tract. Ann Diagn Pathol 2011; 15: 198-201. [CrossRef]

14. Kasperlik-Zaluska AA, Roslonowska E, Slowinska-Srzednicka J, Otto M, Cichocki A, Cwikla J, et al. 1,111 patients with adrenal incidentalomas observed at a single endocrinological center: incidence of chromaffin tumors. Ann N Y Acad Sci 2006; 1073: 38-46. [CrossRef]

15. Miettinen M, Sarlomo-Rikala M, Lasota J. Gastrointestinal stromal tumours. Ann Chir Gynaecol 1998; 87: 278-81. [CrossRef]

16. Jacobson BC, Hirsch MS, Lee JH, Van Dam J, Shoji B, Farraye FA. Multiple asymptomatic plexiform schwannomas of the sigmoid colon: a case report and review. Gastrointest Endosc 2001; 53: 801-14. [CrossRef]

17. Hesselfeldt-Nielsen J, Geerdsen JP, Pedersen VM. Bleeding schwannoma of the small intestine: a diagnostic problem. Case report. Acta Chir Scand 1987; 153:623-5. [CrossRef]

18. Li S, Ai SZ, Owens C, Kulesza P. Intrapancreatic schwannoma diagnosed by endoscopic ultrasound-guided fine-needle aspiration cytology. Diagn Cytopathol 2009; 37: 132-5. [CrossRef]

19. Jiang ZX, Zhang SJ, Peng WJ, Yu BH. Rectal gastrointestinal stromal tumors: imaging features with clinical and pathological correlation. World J Gastroenterol 2013; 19: 3108-16. [CrossRef]

20. Koch MR, Jagannathan JP, Shinagare AB, Krajewski KM, Raut CP, Hornick JL, et al. Imaging features of primary anorectal gastrointestinal stromal tumors with clinical and pathologic correlation. Cancer Imaging 2013; 12: 557-65. [CrossRef]

21. Zhang YM, Lei $P F$, Chen MN, LV XF, Ling YH, Cai PQ, et al. CT findings of adrenal schwannoma. Clin Radiol 2016; 71: 464-70. [CrossRef]

22. Miyake KK, Nakamoto Y, Kataoka TR, Ueshima C, Higashi T, Terashima T, et al. Clinical, morphologic, and pathologic features associated with increased FDG uptake in schwannoma. AJR Am J Roentgenol 2016; 207: 1288-96. [CrossRef]
23. Miettinen M, Shekitka KM, Sobin LH. Schwannomas in the colon and rectum: a clinicopathologic and immunohistochemical study of 20 cases. Am J Surg Pathol 2001; 25: 846-55. [CrossRef]

24. Lasota J, Wasag B, Dansonka-Mieszkowska A, Karcz D, Millward CL, Ryś J, et al. Evaluation of NF2 and NF1 tumor suppressor genes in distinctive gastrointestinal nerve sheath tumors traditionally diagnosed as benign schwannomas: $s$ study of 20 cases. Lab Invest 2003; 83: 1361-71. [CrossRef]

25. Hong HS, Ha HK, Won HJ, Byun JH, Shin YM, Kim AY, et al. Gastric schwannomas: radiological features with endoscopic and pathological correlation. Clin Radiol 2008; 63: 536-42. [CrossRef]

26. Sugimoto M, Takagi T, Suzuki R, Konno N, Asama H, Watanabe K, et al. Endoscopic ultrasonography-guided fine needle aspiration can be used to rule out malignancy in autoimmune pancreatitis patients. J Ultrasound Med 2017; 36:2237-44. [CrossRef]

27. Voltaggio L, Murray R, Lasota J, Miettinen M. Gastric schwannoma: a clinicopathologic study of 51 cases and critical review of the literature. Hum Pathol 2012; 43: 650-9. [CrossRef]

28. Daimaru Y, Kido K, Hashimoto H, Enjoji M. Benign schwannoma of the gastrointestinal tract: a clinicopathologic and immunohistochemical study. Hum Pthol 1988; 19: 257-64. [CrossRef]

29. Melvin WS, Wilkinson MG. Gastric schwannoma. Clinical and pathologic considerations. Am Surg 1993; 59: 293-6. [CrossRef]

30. Inagawa S, Hori M, Shimazaki J, Matsumoto S, Ishii H, Itabashi M, et al. Solitary schwannoma of the colon: report of two cases. Surg Today 2001; 31:833-8. [CrossRef]

\title{
OLGU SERISI-ÖZET
}

\author{
Turk J Surg 2021; 37 (4): 408-412
}

\section{Gastrointestinal schwannomlar ve literatürün kısaca değerlendirilmesi}

\author{
Şükrü Çolak ${ }^{1}$, Bünyamin Gürbulak ${ }^{1}$, Gürhan Çelik ${ }^{1}$, Hasan Bektaş $^{1}$, Nevra Dursun ${ }^{2}$ \\ 1 İstanbul Eğitim ve Araştırma Hastanesi, Genel Cerrahi Kliniği, İstanbul, Türkiye \\ ${ }^{2}$ Istanbul Eğitim ve Araştırma Hastanesi, Patoloji Departmanı, İstanbul, Türkiye
}

\section{ÖZET}

Schwann hücrelerinden kaynaklanan schwannomlar, periferik sinir kılıfından gelişirler ve yavaş büyüyen, çoğunlukla mezenkimden kaynaklanan iyi huylu tümörlerdir. Her iki cinsiyette de eşit olarak görünür. Schwannomalar genellikle 3 ve 5. dekadda görülür. Schwannomalar, periferik sinirlerin görüldüğü her yerde görülebilir. Gastrointestinal schwannomalar tüm submukozal kitlelerin \%2-6'sını oluşturur ve mide en sık görülen alandır (\%60-70). Gastrointestinal submukozal lezyonların endoskopik ultrasonografi (EUS) kılavuzluğunda biyopsisi ile preoperatif ayırıcı tanı mümkündür. 2005 ve Aralık 2017 arasında gastrointestinal schwannomaları tanısı alan hastalar çalışmaya dahil edildi. Altı hastanın üçü kadındı. Yaş ortalaması 52,5 (44-76) idi. Schwannomalar, iki hastada gastrik lokalizasyonda, bir hastada apandiks, iki hastada kolon ve bir hastada perianal bölgede lokalizeydi. Primer schwannomlar genellikle iyi huyludur. Malign dejenerasyon riski nedeniyle temiz sınırlarla radikal rezeksiyon gereklidir; kemo ve radyoterapi yanıtı belirsizdir ve lokal nüks oranları yüksektir.

Anahtar Kelimeler: Gastrointestinal schwannomlar, gastrointestinal submukozal kitleler, immunhistokimya

Doi: $10.47717 /$ turkjsurg.2021.4286 